\title{
LEARNING MATERIAL DEVELOPMENT AS A COPING STRATEGY FOR MANAGING STUDENT STRESS DURING THE PANDEMIC
}

\author{
Rosmala Dewi ${ }^{1}$, ORCID: 0000-0002-6174-7410, \\ Raudah Zaimah Dalimunthe ${ }^{2 *}$, ORCID: 0000-0001-7463-3802, \\ Asiah, ORCID': 0000-0003-2823-1559, \\ Ishaq Matondang ${ }^{1}$, ORCID: 0000-0003-3326-8786, \\ Evans Libra Sianipar ${ }^{1}$, ORCID: 0000-0002-3523-7644, \\ Muhammad Bukhori Dalimunthe ${ }^{1}$, ORCID: 0000-0002-2422-5568 \\ ${ }^{1}$ Universitas Negeri Medan, Jalan Willem Iskandar Pasar V, Medan, Sumatera Utara, Indonesia \\ ${ }^{2}$ Universitas Sultan Ageng Tirtayasa, Jalan Raya Palka Km 3 Sindang Sari, Serang, Banten, Indonesia \\ *Corresponding author: Raudah Zaimah Dalimunthe, raudah@untirta.ac.id
}

Received: 08. 04. 2021

Accepted: 08. 30. 2021

\begin{abstract}
The research problem is the lack of teaching materials as a coping strategy to manage student stress. This study aims to develop effective teaching materials as a coping strategy to manage stress using the Eduda (Education of Drug Adversity) application. A coping strategy is one of the seven life skills that are trained in the Eduda application. Teaching materials are designed and developed on the Eduda application. The research and development design uses the ADDIE (Analysis, Design, Development, Implementation, Evaluation) model. Participants of 29 students who attend SMAN 17 Medan. Data collection techniques used questionnaires, in-depth interviews, and training. Coping strategy teaching materials have passed expert validity from the material and media aspects. After the teaching materials have been successfully developed, training in the use of teaching materials is carried out through the Eduda application. The results show that the teaching materials for coping strategies effectively manage stress in learning during the pandemic. The training achievement supports this finding; as many as 27 (93\%) students have achieved excellent managing stress. The implications of this research impact learning modes that must be flexible in technological and pay attention to coping strategies to overcome the adverse effects of learning during a pandemic.
\end{abstract}

Keywords: stress management skills, Eduda application, ADDIE.

Rezumat. Problema cercetării este lipsa materialelor didactice ca strategie de gestionare a stresului elevilor. Acest studiu își propune să dezvolte materiale didactice eficiente ca strategie de gestionare a stresului utilizând aplicația Eduda (Educația Adversității în Droguri). O strategie de coping este una dintre cele șapte abilități de viață care sunt instruite în aplicația Eduda. Materialele didactice sunt proiectate și dezvoltate pe aplicația Eduda. Proiectarea cercetării și dezvoltării utilizează modelul ADDIE (analiză, proiectare, dezvoltare, implementare, evaluare). Participanți a 29 de studenți care participă la SMAN 17 Medan. 
Tehnicile de colectare a datelor au folosit chestionare, interviuri aprofundate și instruire. Materialele didactice ale strategiei de coping au trecut de validitatea expertului din aspectele materiale și media. După ce materialele didactice au fost dezvoltate cu succes, instruirea în utilizarea materialelor didactice se realizează prin intermediul aplicației Eduda. Rezultatele arată că materialele didactice pentru strategiile de coping gestionează eficient stresul în învățare în timpul pandemiei. Realizarea instruirii susține această constatare; până la 27 (93\%) studenți au atins un stres excelent de gestionare. Implicațiile acestei cercetări au impact semnificativ asupra modurilor de învățare, care trebuie să fie flexibile din punct de vedere tehnologic și să acorde atenție strategiilor de abordare pentru a depăși efectele negative ale învățării în timpul unei pandemii.

Cuvinte cheie: abilități de gestionare a stresului, aplicație Eduda, ADDIE.

\section{Introduction}

Academic stress is the pressure that occurs in academic activities at school [1-3]. As a child transitioning to adulthood, academic, lifestyle, and social pressures can cause stress. Academic stress will occur when students feel their well-being is threatened by academic demands, such as high school achievement expectations, without being balanced with sufficient abilities from within. For example, during a pandemic, students studying at home face many tasks, no friends to discuss learning difficulties. It is not easy to understand the material because they do not meet the teacher, and students do not have confidence in their students' abilities. So that the pandemic situation that causes learning from home adds to the academic stress experienced by students. Most students do not have coping strategies to deal with these problems. In addition, students who have just entered school in a new school environment do not know the teachers, friends, and class conditions required by the learning process using e-learning mode. This is a trigger for academic stress because students are still in a period of adaptation and have not found the right way for the e-learning learning process to overcome the problems that exist in school.

Lefton [4] states that coping is when a person determines several actions to regulate the environment or internal environment that may cause stress. Coping is a hard or strong effort, is continuous, does not occur suddenly, and will change, depending on the problem and the severity of the problem. Papalia [5] describes coping as an essential aspect of mental health, where coping is an adaptive thought or behavior in reducing or relieving stress from painful, dangerous, or challenging conditions. Coping strategies lead to individual efforts or behavior, both mental and behavioral, whose goal is to control, tolerate, reduce or minimize a stressful situation or event. In other words, coping strategy is a process in which individuals try to handle and master stressful situations resulting from the problems they face by changing cognitively and behaviorally to gain a sense of security within themselves [6]. Based on scholars' definition, we define coping stress as a form of individual effort to overcome and minimize stressful situations both cognitively and behaviorally.

The condition of students who experience academic stress certainly has an impact on student learning outcomes themselves as explained from several studies that academic stress experienced by students continuously will result in a decrease in student body resistance so that they are easy to get sick [7 - 9]. If not treated immediately can trigger cardiovascular diseases such as high blood pressure, cholesterol, and heart attacks. In the long term, unresolved stress can affect students' mentality in the form of mental fatigue and discouragement and cause students to experience behavioral problems, make trouble in 
class, behave strangely, self-destruct, passive, explosive emotions, anti-social behavior, aloof, consuming cigarettes, drugs, and alcohol [10].

Several previous studies are exploring the urgency of stress management skills in life. Hakim and Fadilla [11] revealed in their research that the condition that most showed smoking behavior was when teenagers were under pressure, which was $40.80 \%$. When stressed, the behavior of consuming cigarettes is an effort to alleviate emotional problems that are diverted to smoking behavior. There is a significant positive correlation between stress and aggressive behavior in adolescents, which means that the higher the stress, the higher the aggressive behavior; conversely, the lower the stress, the lower the aggressive behavior [12]. Furthermore, research results reveal that adolescent life skills are still low, causing adolescents to initiate drugs. This is due to one of the seven life skills that students lack: the skills to manage stress or cope with stress [13].

Based on the interviews conducted with teachers at SMAN 17 Medan in April 2020, students are still unstable, easily offended, angry, fighting because of trivial problems, which problems should be solved in a good way. Some students do not have coping stress and are low in managing their stress, causing a tendency to decrease enthusiasm for learning, isolate themselves, a link between friends, and assume that other people cause problems. Students exposed to stress also tend to be easily carried away by negative things such as releasing emotions to others because students unknowingly fail to control themselves and injure others. An unstable emotional state interferes with the spirit of learning so that academic tasks are neglected. One teacher revealed that no media for teaching materials at school makes it easier for teachers to prevent or overcome stress during a pandemic. The purpose of the study was to develop teaching materials for coping strategies to manage student stress during the pandemic by utilizing the Eduda application.

\section{Literature}

Academic stress is the pressures that occur within students caused by competition and academic demands $[14,15]$. Academic stress includes students' perceptions of the amount of knowledge that must be mastered and the perception of insufficient time to develop it. According to Pitt et al. [16], academic stress is caused by complex subject matter for students, so that there is a fear of teachers who teach. In addition, pressure due to subjective perception causes student responses in the form of adverse physical reactions, behaviors, thoughts, and emotions that arise due to the demands of learning and school.

During the COVID-19 pandemic, students studied from home, teachers needed online learning materials to strengthen students' live skills in dealing with changes in learning implementation. The Eduda application is prepared to facilitate counseling guidance teachers to carry out counseling learning wherever and whenever they carry out services. The Eduda application consists of 4 sections: teacher educators, student educators, peer counselor educators, parents educators, and teachers [17].

The student's Eduda application contains (1) counseling conversations to peer counselors, parents, and teachers; (2) learning videos to build students' self-restraint through the practice of seven life skills, namely learning skills, time management, spirituality, stress management, critical thinking exercises, problem-solving, and self-leadership; (3) how to detect drug abuse early; 4) seven materials for life skills training and assessment. The following is the content of the Eduda application related to the practice of seven life skills for students. 
Researchers developed teaching materials in materials, learning videos, methods, media, habituation exercise materials, and assessments. Implementation of learning using conventional methods and e-learning using the Eduda application. Teaching materials in the form of books are carried out in conventional learning. Meanwhile, during the current pandemic, researchers use e-learning through the Eduda application. Counseling learning services function to solve problems and, more importantly, the function of prevention so that students achieve the Competency Standards for Student Self-Reliance according to the demands of the 2013 counseling curriculum.

The learning materials developed in this paper are subject matter that is systematically arranged, which is used by teachers and students in the learning process. Learning materials consist of a set of learning tools containing content, media, methods, limitations to achieve competence, and the expected goals in the counseling guidance curriculum. Thus, when students carry out learning activities, they are expected to have changes in themselves, including aspects of attitudes, knowledge, and skills.

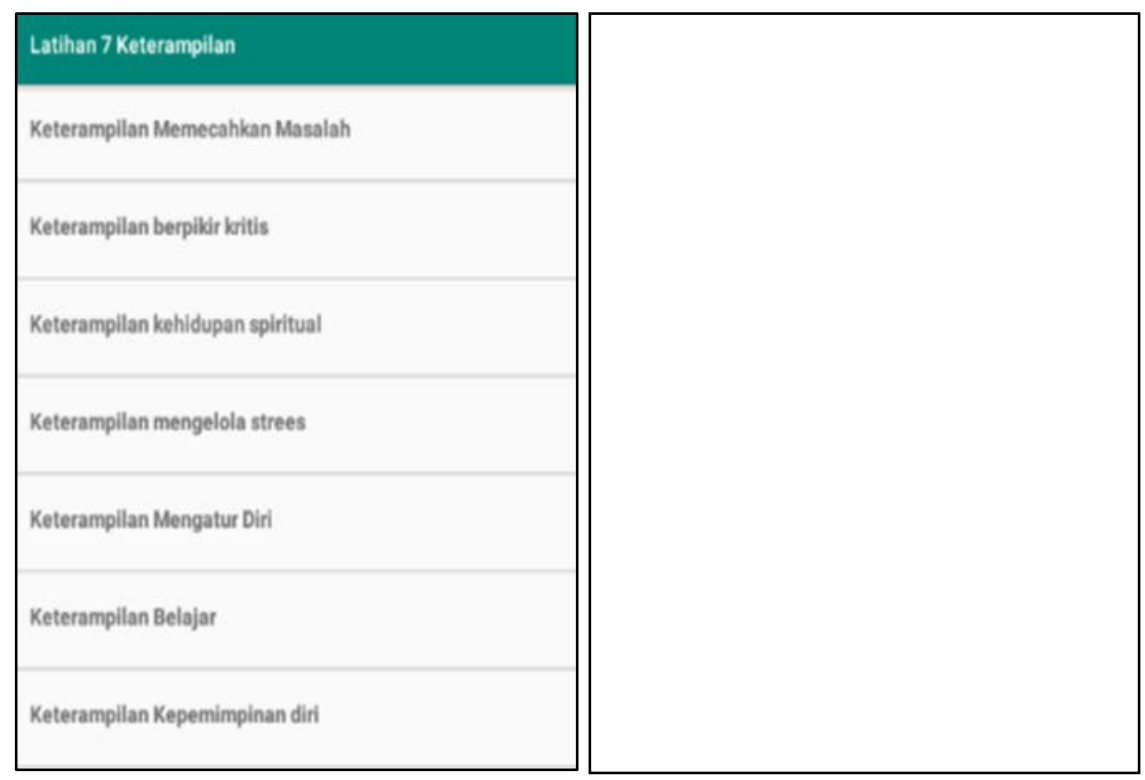

Figure 1. Skill content on the Eduda application.

The developed teaching materials have advantages for teachers to carry out face-toface counseling services and e-learning: (1) The teacher conveys materials for understanding and training on coping strategies to students; (2) Teachers can pay more attention to their daily activities, choosing coping strategies that they will learn; (3) Students can apply and practice healthy living habits in daily activities so that contextually it is more meaningful to understand learning and practice coping strategies.

\section{Method}

The research development design is used in this paper. This study uses the ADDIE model [18]. The research subjects were the first-grade students of SMAN 17 Medan, totaling 29 people who had academic stress disorder from the reports of teachers and parents. The criteria for determining the subject are: 1 ) suspected of being exposed to academic stress; 2 ) students have mobile phones with the Eduda application installed; 3) willing to be actively involved in research; 4) obtain approval from the principal, teachers, and parents. The object in the study of teaching materials for coping strategy skills.

Data collection methods were used in the form of questionnaires and interviews. Questionnaires form a questionnaire on coping strategy skills, a questionnaire to validate the 
material, media, and student responses. Questionnaire of stress management skills using a Likert scale of $1-5$. The purpose of using a questionnaire is to determine how students' stress management skills and responses from academic and media experts are related to the feasibility of teaching materials so that scores are obtained as materials for further product development. At the same time, the interview aims to find out the responses, comments, and suggestions of teachers and students after using learning media.

Product validation questionnaires from material experts are compiled based on the characteristics of teaching materials, namely self-instructional, self-contained, stand-alone, adaptive, and user friendly [19]. Meanwhile, product validation by media experts is based on face validation that uses three assessment aspects, namely size, cover design, and content design $[20,21]$

\section{Results and Discussion}

\section{Analysis Stage}

The researchers analyzed students' needs, characteristics, and initial abilities at this stage and analyzed the availability of facilities, support, the counseling guidance curriculum, and student development tasks. As a result, the results of the study were found: 1) students needed teaching materials, according to the situation of students having difficulty controlling emotions, and according to the counseling guidance curriculum but teaching materials for coping strategies during the pandemic were not available at school; and 2) from the number of respondents 29 students, there are 25 students with low coping strategies.

\section{Design Stage}

The stage of designing teaching materials for coping strategies consists of 4 steps, namely: preparation of the framework of teaching materials, collection and selection of references, preparation of designs and features of teaching materials, and preparation of teaching materials assessment instruments. At this stage, the following activities are carried out: 1) determine the structure of the material; 2) multimedia specifications developed for the Eduda application program; 3) create story boards, designs and features of teaching materials; 4) prepare the material in the form of learning videos; 5) preparation of material expert validation instruments, media and student responses; 6) identify the technology supporting the production of teaching materials to the Eduda application. The research findings reveal: 1 ) the arrangement of teaching materials into three parts, beginning, content and ending; 2) found multimedia specifications; 3) the arrangement of the design and features of teaching materials in the form of covers, rules for using books, competencies to be achieved, materials, exercises, assessments, reflections and references; 4) materials in the form of learning videos and printed materials; 5$)$ the preparation of media validation instruments, material validation and student response questionnaires; 6 ) the appearance of teaching materials on coping strategies in the Eduda application.

\section{Development Stage}

At this stage, expert validation (media and materials), revision of teaching materials, and field validation results. This stage provides information that the validation from the experts has been fulfilled, and the revision is composed of criticism by media experts and material experts and student responses to teaching materials.

\section{Implementation Stage}

At this stage, they were applying teaching materials for coping strategies through the Eduda application. It was found that students understood, applied the material, and exercised 
coping strategies through the Eduda application and received an assessment. The findings at this stage align with research conducted by Dalimunthe and Dewi [22], which reveals that Eduda is effective as a counseling medium. The researcher initially introduced the Eduda application (Education of Drugs Adversity) as a research forum, and the researchers also guided students in downloading the Eduda application. Before using the Eduda application, the researcher directed students to create a personal account that would be used to log in to the Eduda application. After the account was registered, the researcher directed the students to enter the Eduda application and fill out the coping strategy exercise. Coping strategy exercises contain habituation exercises that are associated with aspects of managing stress. Excessive learning tasks, short working time lead to stress on students [23]. Stress can harm a person's physical and mental, characterized by physical, emotional, intellectual, and interpersonal symptoms. Difficulty sleeping, tired quickly, often feeling tired, muscle tension, and even diarrhea are physical symptoms of stress [24].

\section{Evaluation Stage}

At this stage, an assessment of teaching materials for stress management skills is carried out through student training and student responses. The evaluation involves education and information technology experts who evaluate the content and appearance of teaching materials developed at Eduda. They believed that teaching materials were worthy of widespread use and several improvements, such as more attractive colors and background displays. All suggestions from experts have been made to improve the quality of teaching materials for stress management skills.

\section{Conclusion}

The teaching materials for stress management skills that have been developed have been effectively used. This can be seen based on the results of student training, which shows that from 29 students, 27 students have passed in filling out the exercises on teaching materials with a percentage of $93.10 \%$. The teaching materials have been effective because the overall graduation percentage achieved a good classification with a percentage of $92.41 \%$. It is recommended that the teaching materials for coping with stress in this Eduda program are used by teachers to facilitate counseling services that still exist and are needed by students, especially during the pandemic.

Acknowledgments: The authors thank Universitas Negeri Medan and various parties who supported the implementation of this research. Universitas Negeri Medan fully funds this research with a fundamental research scheme, grant number 0185/UN33.8/PL-PNBP/2021.

\section{References}

1. A. Abdollahi, S. Panahipour, M. Akhavan Tafti, and K. A. Allen, "Academic hardiness as a mediator for the relationship between school belonging and academic stress," Psychol. Sch., vol. 57, no. 5, pp. 823-832, May 2020, doi: https://doi.org/10.1002/pits.22339.

2. J. de la Fuente, J. Amate, M. C. González-Torres, R. Artuch, J. M. García-Torrecillas, and S. Fadda, "Effects of Levels of Self-Regulation and Regulatory Teaching on Strategies for Coping With Academic Stress in Undergraduate Students," Front. Psychol., vol. 11, p. 22, 2020, doi: https://doi.org/10.3389/fpsyg.2020.00022.

3. G. M. Calaguas, "College academic stress: Differences along gender lines," J. Soc. Dev. Sci., vol. 1, no. 5, pp. 194-201, 2011, doi: https://doi.org/10.22610/jsds.v1i5.644.

4. L. A. Lefton, Psychology 6th Edition. London: Allyn \& Bacon, 1996.

5. D. E. Papalia, H. L. Sterns, R. D. Feldman, and C. J. Camp, "Adult development and aging, 3rd ed.," Adult development and aging, 3rd ed. McGraw-Hill, New York, NY, US, pp. xv, 524-xv, 524, 2007. 
6. C. S. Carver, M. F. Scheier, and J. K. Weintraub, "Assessing coping strategies: A theoretically based approach.," Journal of Personality and Social Psychology, vol. 56, no. 2. American Psychological Association, US, pp. $267-$ 283, 1989, doi: 10.1037/0022-3514.56.2.267.

7. P. Frazier, A. Gabriel, A. Merians, and K. Lust, "Understanding stress as an impediment to academic performance," J. Am. Coll. Heal., vol. 67, no. 6, pp. 562-570, Aug. 2019, doi: 10.1080/07448481.2018.1499649.

8. W. W. S. Lee, "Relationships among grit, academic performance, perceived academic failure, and stress in associate degree students," J. Adolesc., vol. 60, pp. 148 - 152, 2017, doi: https://doi.org/10.1016/j.adolescence.2017.08.006.

9. Y. Luo, Y. Deng, and H. Zhang, "The influences of parental emotional warmth on the association between perceived teacher-student relationships and academic stress among middle school students in China," Child. Youth Serv. Rev., vol. 114, p. 105014, 2020, doi: https://doi.org/10.1016/j.childyouth.2020.105014.

10.R. Dewi, M. Fitri Rahmadana, W. Pangaribuan, and M. Bukhori Dalimunthe, "Self-Resilience Model of Drug Initiation and Drug Addiction (A Structural Equation Model Approach)," Arch. Psychiatry Res., vol. 56, no. 1, pp. 5-18, Feb. 2020, doi: 10.20471/may.2020.56.01.01.

11. H. M. Z. Hakim and A. Fadilla, "Community Perception of Cigarette Consumption Control Policy: A Case Study of Bogor Municipality, West Java," J. Aisyah J. Ilmu Kesehat., vol. 6, no. 1, pp. 103-108, 2021, doi: 10.30604/jika.v6i1.445.

12. M. D. Pérez-Fuentes, M. D. Molero Jurado, A. B. Barragán Martín, and J. J. Gázquez Linares, "Family Functioning, Emotional Intelligence, and Values: Analysis of the Relationship with Aggressive Behavior in Adolescents," International Journal of Environmental Research and Public Health, vol. 16, no. 3. 2019, doi: 10.3390/ijerph16030478.

13. R. Dewi, M. F. Rahmadana, W. Pangaribuan, and M. B. Dalimunthe, "Model Membangun Ketahanan Diri Terhadap Inisiasi dan Pembiasaan Narkoba Menggunakan Aplikasi Edu-DA," Medan, 2018.

14.K. Wenzel and M.-A. Reinhard, "Does the end justify the means? Learning tests lead to more negative evaluations and to more stress experiences," Learn. Motiv., vol. 73, p. 101706, 2021, doi: https://doi.org/10.1016/j.lmot.2020.101706.

15.J. Ying, J. You, and J. Guo, "The protective effects of youth assets on the associations among academic stress, regulatory emotional self-efficacy, and suicidal risk: A moderated mediation model," Child. Youth Serv. Rev., vol. 119, p. 105660, 2020, doi: https://doi.org/10.1016/j.childyouth.2020.105660.

16. A. Pitt, F. Oprescu, G. Tapia, and M. Gray, "An exploratory study of students' weekly stress levels and sources of stress during the semester," Act. Learn. High. Educ., vol. 19, no. 1, pp. 61 - 75, Sep. 2017, doi: 10.1177/1469787417731194.

17.R. Dewi, R. Z. Dalimunthe, M. F. Rahmadana, W. Pangaribuan, M. B. Dalimunthe, and others, Membangun Ketahanan Diri Anak Remaja Melalui Program Eduda (Education of Drugs Adversity). Yayasan Kita Menulis, 2019.

18. W. Dick, L. Carey, and J. O. Carey, The Systematic Design of Instruction. Pearson Education, 2014.

19. N. C. Gysbers and P. Henderson, Developing and managing your school guidance and counseling program. John Wiley $\backslash \&$ Sons, 2014.

20. R. Z. Dalimunthe, R. Dewi, and M. B. D. Martiano, "Validation of Eduda Applications and Self Resilience," in ICONSEIR 2019: Proceedings of the 2nd International Conference of Science Education in Industrial Revolution 4.0, ICONSEIR, December 17th, 2019, Medan, North Sumatra, Indonesia, 2020, p. 388.

21.D. Mardapi, Pengukuran, Penilaian, dan Evaluasi Pendidikan (Edisi 2). Yogyakarta: Parama, 2017.

22.R. Z. Dalimunthe and R. Dewi, "Implementasi Aplikasi Eduda sebagai Media Pembelajaran Konseling Membangun Ketahanan Diri Siswa Mencegah Narkoba," in Prosiding Seminar Bimbingan dan Konseling, 2020, pp. $27-35$.

23. B. M. Gadzella, M. Baloglu, W. G. Masten, and Q. Wang, "Evaluation of the Student Life-stress InventoryRevised.," J. Instr. Psychol., vol. 39, no. 2, 2012.

24. R. Kupriyanov and R. Zhdanov. "The eustress concept: problems and outlooks," World J. Med. Sci., vol. 11, no. 2, pp. 179 - 185, 2014, doi: 10.5829/idosi.wjms.2014.11.2.8433. 